\title{
LAYERED STRUCTURE OF THE UPPER MANTLE BENEATH THE SIBERIAN PLATFORM: PETROLOGICAL AND GEOPHYSICAL DATA.
}

\section{L.V. Solovjeva and L.L. Zavjalova.}

Institute of the Earth Crust, 664033 - Yakutsk, USSR.

P-T data for deep-seated xenoliths from kimberlites in Yakutia, obtained by thermobarometric methods, reveal layered stratified structure of the mantle in the Udachnaya pipe area (the central part of the platform) to the depth of $220 \mathrm{~km}$ and in the Obnazhennaya pipe area (Olenek uplift) down to $120 \mathrm{~km}$. The mantle in the central part of the platform to the depth of $180 \mathrm{~km}$ is recognized to be largely composed of restite spinel, spinel-gainet and garnet Iherzolites and harzburgites, and by horizons of pyroxenites, websterites, olivine websterites occuring between $60-78 \mathrm{~km}, 90-96 \mathrm{~km}$ and 141-171 km depths.

These three horizons are affined in their depth and thickness to low velocity layers recorded beneath the Siberian platform according to the deep seismic sounding data (Egorkin et al., 1984). Two layers of rocks of pyroxenite-websterite series approximately corresponding to the upper layers in the mantle lithosphere under the central part of the platform, are distinguished under the crust in the Obnazhennaya pipe area. A detailed study of petrography, petrochemistry and mineralogy of rocks from pyroxenite-websterite series indicate that they are commonly cumulates of the former ultramafic melts of komatiitic type and more seldom are products of total crystallization of such melts, which existed in the ancient mantle lithosphere at corresponding depths in the form of large intrusive sheets.

The roof of the lower low velocity layer on the seismic profile under the central part of the platform (depth of $190 \mathrm{~km}$ ) conforms to the upper part of the zone corresponding, according to P-T data, to sheared peridotites whose origin is more often related 
to the asthenosphere. There is some vertical displacement of the four layers revealed by petrological methods, relative to the low velocity layers determined by geophysical data.

The geotherm constructed on the samples from the Udachnaya pipe is close to that with the heat flow of $40 \mathrm{~mW} / \mathrm{m}^{2}$ and to an empiric geotherm by F.R.Boyd (1984) for the same pipe. The pristine geotherm is also reconstructed after the relict exsolution ortopyroxenes in harzburgites. and Iherzolites of restite type, which is $200-300^{\circ} \mathrm{C}$ higher than that of the last chemical equilibrium in samples. This temperature difference as well as a probable presence of large intrusive sheets of komatiite melts in the ancient mantle lithosphere suggest the continuous hot stage in the life of the upper mantle followed by the stage of long term cooling. The latter is quite distinctly determined by unidirectional reaction of replacement of spinel paragenesises by garnet ones, recorded everywhere in deep-seated xenoliths from kimberlites in different regions of the world. The ancient stage of metasomatism was manifested in already cooled rigid and brittle lithosphere in the form of mineral products. The estimation of the bulk composition of the mantle lithosphere in the Udachnaya pipe area according to the balance of pyroxenite-websterite and harzburgite-lherzolite layers, show that the mantle was sufficiently depleted in basaltoid components ( $\mathrm{TiO}_{2}$, $\mathrm{Al}_{2} \mathrm{O}_{3}, \mathrm{FeO}, \mathrm{CaO}, \mathrm{Na}_{2} \mathrm{O}$ ) already during the hot stage of its existence. 